\title{
Supervisors' Feedback and Teacher Professional Development in a Context of Students' Linguistic Diversity in OECD Countries
}

\author{
Yesifa Azovide, Yamina Bouchamma \\ Université Laval, Québec, Canada \\ Email: koudjo-afuwu-yesifa.azovide.1@ulaval.ca,yamina.bouchamma@fse.ulaval.ca
}

How to cite this paper: Azovide, Y., \& Bouchamma, Y. (2021). Supervisors' Feedback and Teacher Professional Development in a Context of Students' Linguistic Diversity in OECD Countries. Creative Education, 12, 2934-2953.

https://doi.org/10.4236/ce.2021.1212220

Received: October 21, 2021

Accepted: December 26, 2021

Published: December 29, 2021

Copyright (อ 2021 by author(s) and Scientific Research Publishing Inc. This work is licensed under the Creative Commons Attribution International License (CC BY 4.0).

http://creativecommons.org/licenses/by/4.0/ (c) (i) Open Access

\begin{abstract}
Teacher professional development was examined in the context of student linguistic diversity in countries of the Organisation for Economic Cooperation and Development (OECD). Data for this quantitative study were taken from the OECD Teaching and Learning International Survey (TALIS, 2013) with teachers $(\mathrm{N}=170,005)$ from 6500 schools. Factor analyses enabled us to identify two factors associated with teacher professional development and two factors pertaining to the teachers' perceptions of their supervisor's feedback on such aspects as skills development and career perspectives, collaboration and support actions with the students, and teaching and assessment practices. Our results show that skills and professional growth development correlated differently depending on the importance the teachers gave to the feedback they received in the presence or absence of linguistic diversity in their classroom. Implications of this diversity on the teachers' perceptions are discussed, as well as socioprofessional characteristics and teacher professional development.
\end{abstract}

\section{Keywords}

Teacher Supervision, Teacher Professional Development, Linguistic Diversity, Skills Development, Career Development, OECD Teaching and Learning International Survey (TALIS, 2013)

\section{Introduction}

Diversity management is central in modern education policies and is drawing greater attention in terms of its place in the public arena and how it is welcomed 
(Cameron et al., 2011; Castles, 2010; De Witte, 2018; Czaika \& de Haas, 2014; Hall \& Posel, 2019; Koser, 2016; McAuliffe \& Khadria, 2020; Triandafyllidou, 2018). Today's debate is focused on the school, which welcomes more and more immigrant students, as is the case of schools in OECD countries, where the number of students younger than 15 years of age whose first language differs from the language of instruction is indeed on the rise (Appave \& David, 2017; Demireva, 2017; Deniger et al., 2013; Somers, 2018). This situation requires the involvement of both supervisors and their supervised teachers, who are front-line stakeholders in the inclusion of immigrant students. Supervisors in their role of pedagogical leader are thus called upon to manage and accommodate this cultural and linguistic diversity on a daily basis (Bouchamma, 2011; Bouchamma \& April 2021; OECD, 2018; Panagiotopoulou \& Rosen, 2018; Somers, 2018). One effective approach supported by extensive research is teacher supervision (Appave \& David, 2017; Brown \& Medway, 2007; Castles et al., 2002; Demireva, 2017; Duval et al., 2014; Newland, 2017; Silver, 2015; Zetter et al., 2006). Indeed, in many contexts, school leaders as a supervisor must take on the role of pedagogical leader in addition to that of head administrator (Bouchamma, 2008, 2009, 2015; Crum \& Sherman, 2008; Dinham, 2005; Leithwood et al., 2004).

Teacher supervision is known to significantly contribute to teacher professional growth and successful schools (Bouchamma, 2005; Bouchamma \& Tardif, 2011). In these effective schools, the supervisor uses strong pedagogical leadership, provides the necessary material resources, ensures differentiated and adapted supervision for their teachers, holds regularly scheduled meetings for this purpose, and encourages discussion to favour professional development that considers the points of view of both supervisor and supervisee (Bouchamma, 2005; Bouchamma \& Tardif, 2011; Oliva \& Pawlas, 2001; Nolan \& Hoover, 2008).

Supervision makes it possible to gather teaching and learning data, provide constructive feedback, and propose adjustments to better suit the students' needs (Bouchamma, 2005; Branch, Hanushek, \& Rivkin, 2012; Dionne et al., 2013; Hoy \& Hoy, 2003; Kluger \& DeNisi, 1996; Marzano et al., 2011; Memduhoglu, 2012; Ovando, 2005; Zepeda, 2012). In other words, teacher supervision becomes a relevant steppingstone in a teacher's professional development, and even more so in a context of student linguistic diversity.

Although there is much research on the subject of teacher supervision and the perspectives of both sides in a homogeneous context, little is known regarding this dynamic in a context of increased diversity in OECD countries, where teachers must work with several different linguistic groups of students at a time (Cooper, 2009; Lindsey et al., 2009; Ovando \& Harris, 1993). Because of the scarceness of literature on the subject, we deemed it timely to expand on the actions required to provide effective sustained supervision that supports the professional development of these teachers (Datnow \& Castellano, 2001; Marks \& Nance, 2007). This concept is explored in the following section as we highlight the connections with the pedagogical supervision. 


\section{Review of the Literature}

In OECD countries, school leaders are responsible for implementing education policies in their school and must consolidate the values upholding "living together", particularly in the face of increasing student linguistic diversity (De Witte, 2018; Hall \& Posel, 2019; Koser, 2016; McAuliffe \& Khadria, 2020; Triandafyllidou, 2018). To achieve this, supervisors must ensure that their teachers continuously hone and adjust their teaching practices to meet their students' needs (Broadfoot, 2000; Maroy, 2005). In this regard, research appears to indicate that the principal's leadership has an impact on optimizing their teachers' pedagogical role, motivation, and commitment (Bouchamma \& April, 2021; Bouchamma \& Tardif, 2011; Collerette et al., 2013). The teacher's pedagogical role is developed with the help of feedback from inside (principal, colleagues) as well as outside (students' parents, Ministry of Education, local education administrators) sources (Tobin, 2008); indeed, feedback is a vital sounding board to help teachers introduce positive changes in how they teach. Studies on the subject of teacher supervision highlight numerous positive effects, including increased accountability and better collaboration (Bouchamma, 2005; DuFour et al., 2004; Marshall, 2005; Nolan \& Hoover, 2008; Robinson, 2007; Silva \& Dana, 2001), as well as improved self-efficacy, healthier social relationships, and better interactions with the teaching supervisor, all factors that nurture teacher professional growth and take into account their needs and expectations (Coburn, 2004; Dumay et al., 2013; Laveault et al., 2014).

In our review of the literature, one recurring theme is that instructional supervision enables principals to support a form of teacher professional development throughout their career.

\section{Objectives}

Many studies have documented the importance given to the supervisors' instructional leadership and just how vital their feedback is to their teachers to help them adjust their practices (Bouchamma, 2005; DuFour et al., 2004; Marshall, 2005; Nolan \& Hoover, 2008; OECD, 2018; Robinson, 2007; Silva \& Dana, 2001). However, little is known on this, and the effects of feedback provided to teachers in contexts of linguistic diversity in the classroom. In this study, we sought to identify the relationships between teacher professional development and the importance teachers give to their supervisor's feedback, in a context of linguistic diversity in the classroom and taking into account the teachers' socioprofessional characteristics.

\section{Methodology}

\subsection{Questionnaire}

Secondary data retrieved in part from the TALIS 2013 teacher questionnaire was used in the present study, namely, data pertaining to questions $1,5 \mathrm{~A}, 5 \mathrm{~B}$, 
11, 29, 30, and 35A (see Appendix 2) regarding the following teacher-related aspects:

- Sociodemographic and socioprofessional characteristics: (1) gender; (5A) teaching experience in the school; (5B) overall teaching experience; (11) teaching certification.

- Degree of importance given to the supervisor's feedback (Question 29);

- Professional development (Question 30); and

- Presence of linguistic diversity in the classroom (Question 35A).

\subsection{Sample}

The participants were lower secondary school teachers $(\mathrm{N}=170,005 ; 32.8 \%$ male $(\mathrm{N}=55,787), 62.2 \%$ female $(\mathrm{N}=114,218)$ ) from 6500 public and private schools in 34 OECD countries. Of these teachers, $87 \%(\mathrm{~N}=147,864)$ had a teaching degree and $45.9 \%(\mathrm{~N}=76,467)$, upon entering the profession, benefited from an initiation program supervised by experienced teachers. These teachers taught students whose first language was different than the language of instruction in various levels of diversity: absence ( $0 \%)$; low (1\% - 10\%); average (11\% - 30\%) and high (31\% or more) in the classroom (Table 1$)$. Based on their practice, they received feedback from their supervisors (principals, mentors, colleagues), students and their parents.

Table 1. Presence of linguistic diversity in the classroom.

\begin{tabular}{ccc}
\hline Students' Linguistic Diversity & Frequency & Proportion \\
\hline Absent & 85,442 & $52.5 \%$ \\
Low & 46,274 & $28.5 \%$ \\
Average & 13,194 & $8.1 \%$ \\
High & 8031 & $4.9 \%$ \\
Very high & 9680 & $6.0 \%$ \\
\hline
\end{tabular}

$\mathrm{N}=162,621$.

\subsection{Variables}

The two dependent variables associated with teacher professional development, namely, Skills development and Career development, were extracted from a factor analysis of the 14 items in Question 30 (see Table 2), while the following teacher-related independent variables were identified from a factor analysis of the 11 items in Question 29 (see Table 3): 1) Importance given to the feedback on my collaboration and support practices with the students, 2) Importance given to the feedback on my teaching and assessment practices, 3) Sociodemographic characteristics (Teacher's gender); 4) Socioprofessional aspects (Teaching certification, Number of years of experience in the school, and Overall teaching experience); and 5) Contextual considerations (Level of linguistic diversity in the classroom). 


\subsection{Data Analysis}

We performed our data analysis using the SPSS v27 statistical software. Following the factor analyses, we conducted a Pearson correlation test to assess the connection between the dependent and independent variables. Multiple regression analyses were also performed to demonstrate the combined effects of our independent variables on the development of the teachers' professional competencies and career perspectives.

\section{Results}

\subsection{Factor Analysis}

Table 2 shows that the factor analysis of the 14 items (Question 30) pertaining to teacher professional development produced two factors explaining $63.89 \%$ of the total variance.

Skills development was found to be the main factor responsible for $36.045 \%$ of the total variance and grouping items 30J (Pedagogical practices), 30I (Knowledge and mastery of the main subject field(s); 30L (Use of students' results to improve their learning); $30 \mathrm{H}$ (In-class management practices); 30M (Professional satisfaction); 30N (Motivation); 30F (Confidence in my teaching abilities); and $30 \mathrm{~K}$ (Teaching practices with special needs students).

The second factor, Career perspectives, explained $27.845 \%$ of the total variance and consisted of items 30C (Promotion perspectives); 30B (Participation in school development initiatives); 30D (Participation in continuing education activities; 30E (Professional responsibilities in this school); 30A (Public recognition from the principal and/or colleagues); and finally, 30G (Salary and/or financial compensations). The Kaiser-Meyer-Olkin (KMO) index measuring sampling quality was .941, which was considered excellent because it was higher than .5 . The Cronbach's alpha obtained for all 14 items of Question 30 was .939, which was also excellent, exceeding the threshold of .6.

Table 2. Teacher professional development (Question 30).

\begin{tabular}{lc}
\hline \multirow{2}{*}{ Items } & \multicolumn{2}{c}{ Factors } \\
\cline { 2 - 2 } & $\begin{array}{c}\text { Skills } \\
\text { development } \begin{array}{c}\text { Career } \\
\text { Development }\end{array}\end{array}$ \\
\hline 30J Teaching practices & .842 \\
30I Knowledge and understanding of my main subject(s) & .778 \\
30L Use of students' assessments to improve their learning & .776 \\
30H In-class management practices & .761 \\
30M Professional satisfaction & .714 \\
30N Motivation & .707 \\
30F Confidence in my teaching abilities & .662 \\
30K Teaching practices with special needs students & .628
\end{tabular}




\section{Continued}

30C Promotion perspectives

30B Participation in school development initiatives

30D Participation in continuing education activities

30E School's professional responsibilities

30A Public recognition by the principal and/or colleagues

Table 3 presents the two factors emanating from our factor analysis of the 11 items related to the value the teachers gave to their supervisor's feedback (Question 29), which explained $59.59 \%$ of the total variance.

The first factor, Importance given to the feedback on my collaboration and support practices with the students, was determined as the main factor responsible for $48.71 \%$ of the total variance and contained the following items: $29 \mathrm{I}$ (Comments from the students' parents or guardians); $29 \mathrm{H}$ (Comments made to other teachers to help them improve their teaching practices); 29J (Students' comments); 29K (Comments on how I work/collaborate with other teachers); 29G (Comments on how I teach in multicultural/multilingual settings); and 29F (Comments on how I teach special needs students).

The second factor Importance given to the feedback on my teaching and assessment practices explained $10.845 \%$ of the total variance and housed the following items: 29C (Comments on my teaching competency in my main subject field(s); 29B (Comments on my knowledge and mastery of my main subject field(s) I; 29D (Comments on my student assessment practices); 29E (Comments on my student behavior/classroom management practices; and finally, 29A (Comments on my students' performance). The recorded KMO measurement was .902, which was considered excellent, as it was higher than .5. The Cronbach's alpha obtained for all 14 items of Question 30 was .892, which was also excellent, as it was over .6.

Table 3. Importance given to the supervisor's feedback (Question 29).

\begin{tabular}{|c|c|c|c|}
\hline & & Factor & \\
\hline & Items & Feedback on my & Feedback on my \\
\hline $29 \mathrm{I}$ & Feedback from the students' parents or guardians & .806 & \\
\hline $29 \mathrm{H}$ & $\begin{array}{l}\text { Feedback made to other teachers to help them improve their teaching } \\
\text { practices }\end{array}$ & .771 & \\
\hline 29丁 & Students' feedback & .748 & \\
\hline $29 \mathrm{~K}$ & Feedback on how I work/collaborate with other teachers & .719 & \\
\hline $29 \mathrm{G}$ & Feedback on how I teach in multicultural/plurilingual settings & .646 & \\
\hline $29 \mathrm{~F}$ & Feedback on how I teach special needs students & .566 & \\
\hline
\end{tabular}




\section{Continued}

29 Feedback on my teaching skills in my main subject(s)

29B Feedback on my knowledge and mastery of my main subject(s)

29D Feedback on my student assessment practices

29E Feedback on my student behavior/classroom management practices

\subsection{Correlations}

A correlation analysis was performed to compare the level of linguistic diversity in the classroom and the following eight variables: Feedback on my collaboration/support practices with the students, feedback on my teaching/assessment practices, skills development, career perspectives, and the teacher's sociodemographic and socioprofessional characteristics, (gender, teaching experience in the school; overall teaching experience, and certification). Results are presented in Table 4.

Significant weak negative correlations were found between students linguistic diversity and five variables:

- Importance given to the feedback on my collaboration/support practices with the students $(\mathrm{r}=-.018 ; p<.01)$ : The teachers were shown to value this feedback less when linguistic diversity in the classroom increased;

- Importance given to the feedback on my teaching/assessment practices $(\mathrm{r}=$ $-.038 ; p<.01)$ : The teachers were shown to value this feedback less when linguistic diversity in the classroom increased;

- Skills development $(\mathrm{r}=-.050 ; p<.01)$ : This factor decreased when linguistic diversity in the classroom increased;

- Teaching experience in the school $(\mathrm{r}=-.068 ; p<.01)$ : This factor decreased when linguistic diversity in the classroom increased; and

- Overall teaching experience $(\mathrm{r}=-.074 ; p<.01)$ : This factor decreased when linguistic diversity in the classroom increased.

However, when the level of linguistic diversity in the classroom decreased:

- When the teachers gave more importance to feedback on my collaboration/ support practices with the students and my teaching/ assessment practices;

- When skills development, teaching experience in the school, and overall teaching experience increased.

Significant weak positive correlations were observed between linguistic diversity in the classroom and three variables:

- Career perspectives $(\mathrm{r}=.018 ; p<.01)$ : This factor increased when linguistic diversity in the classroom increased and decreased when linguistic diversity in the classroom decreased;

- Teachers' gender $(\mathrm{r}=.010 ; p<.01)$ : The gender was male when linguistic diversity in the classroom increased and female when this diversity decreased;

- Teachers' certification $(\mathrm{r}=.076 ; p<.01)$ : The number of certified teachers increased when linguistic diversity in the classroom increased, yet decreased 
when linguistic diversity in the classroom decreased.

A significant weak negative correlation was found between the importance given to feedback on my collaboration/support practices with the students and two variables:

- Teachers' gender $(\mathrm{r}=-.040 ; p<.01)$ : The teachers valued this factor less when the gender of the teachers was male;

- Teachers' certification $(\mathrm{r}=-.013 ; p<.01)$ : The teachers valued this factor less when they possessed a teaching degree.

On the other hand, the teachers gave greater value to feedback on my collaboration/support practices with their students when their gender was female and the teachers were not certified.

Significant weak positive correlations were observed between the importance given to the feedback on my collaboration/support practices with the students and four variables:

- Skills development $(\mathrm{r}=.298 ; p<.01)$ : This factor was shown to increase when the participants gave greater value to the feedback on my collaboration/support practices with the students and diminished when they gave less importance to this feedback;

- Career perspectives $(\mathrm{r}=.278 ; p<.01)$ : This factor increased when the teachers gave more importance to the feedback given on my teaching/assessment practices and decreased when the teachers this feedback less;

- Teaching experience in the school $(\mathrm{r}=.036 ; p<.01)$ : The teachers gave more importance to the feedback on my collaboration/support practices with the students when their teaching experience in the school increased and less importance when this particular feedback decreased;

- Overall teaching experience $(\mathrm{r}=.085 ; p<.01)$ : The teachers valued the feedback on my collaboration/support practices with the students more when overall teaching experience increased and less when overall teaching experience decreased.

A significant weak negative correlation was found between the importance given to the feedback on my teaching/assessment practices and teachers' gender $(\mathrm{r}=-.104 ; p<.01)$, as male teachers were found to give less value to feedback on my teaching/assessment practices, compared to their female peers who awarded greater importance to this factor.

Significant weak positive correlations were established between the importance given to the feedback on my teaching/assessment practices and four variables, as follows:

- Skills development $(\mathrm{r}=.280 ; p<.01)$ : Skill development was shown to increase when the participants gave greater value to feedback on their teachinglassessment practices and decrease when they gave less value to this feedback;

- Career perspectives $(\mathrm{r}=.178 ; p<.01)$ : Career development was shown to increase when the teachers gave greater value to feedback on my teaching/assessment practices and decrease when the teachers felt less strongly about this 
feedback;

- Teaching experience in the school $(\mathrm{r}=.010 ; p<.01)$ : The teachers gave more importance to the feedback on my teaching/assessment practices when the number of years of experience in the school increased and less importance when this experience decreased;

- Overall teaching experience $(\mathrm{r}=.009 ; p<.01)$ : The teachers gave greater importance to feedback on my teaching/assessment practices when their overall teaching experience increased and less so when their overall teaching experience decreased.

Significant weak negative correlations were observed between skills development and four variables:

- Teachers' gender $(\mathrm{r}=-.048 ; p<.01)$ : Skills development decreased when the teachers were male;

- Teaching experience in the school $(\mathrm{r}=-.024 ; p<.01)$ : Skills development decreased when teaching experience in the school increased;

- Overall teaching experience $(\mathrm{r}=-.022 ; p<.01)$ : Skills development decreased when the overall experience increased;

- Certification $(\mathrm{r}=-.071 ; p<.01)$ : Skills development decreased when the teachers were shown to have a teaching diploma.

However, skills development increased when the teachers' gender was female, when teaching experience in the school and overall teaching experience decreased, and when they had no certification.

Significant weak negative correlations were found between the teachers' career perspectives and two variables:

- Teaching experience in the school ( $\mathrm{r}=-.019 ; p<.01)$ : Career perspectives was shown to decrease when this variable increased;

- Overall teaching experience $(\mathrm{r}=-.028 ; p<.01)$ : Career perspectives were shown to decrease when overall teaching experience increased.

However, Career perspectives increased when both Teaching experience in the school and Overall teaching experience decreased.

A significant weak positive correlation was observed between Career perspectives and two variables:

- Teachers' gender $(\mathrm{r}=.031 ; p<.01)$ : The teachers' career perspectives increased when the gender was male and decreased when the gender was female;

- Teachers' certification $(\mathrm{r}=.017 ; p<.01)$ : Career perspectives increased when the teachers were certified and decreased when they were not.

Table 4. Correlations found between the different factors.

\begin{tabular}{|c|c|c|c|c|c|c|c|c|c|}
\hline Factors & 1 & 2 & 3 & 4 & 5 & 6 & 7 & 8 & 9 \\
\hline 1. Linguistic diversity in the classroom & - & & & & & & & & \\
\hline $\begin{array}{l}\text { 2. Feedback on my collaboration and } \\
\text { support practices with the students }\end{array}$ & $-.018^{\star \star}$ & - & & & & & & & \\
\hline
\end{tabular}




\section{Continued}

3. Feedback on my teaching and assessment practices

$$
\begin{aligned}
& -.038^{\star *} \quad .000 \\
& \begin{array}{llll}
-.050^{* *} & .298^{* *} & .280^{* *} \quad-
\end{array} \\
& \begin{array}{llll}
.018^{\star *} & .278^{\star *} & .178^{\star *} & .000
\end{array} \\
& .010^{\star *}-.040^{\star *}-.104^{\star \star}-.048^{\star *} \quad .031^{\star \star} \quad- \\
& \begin{array}{llllll}
-.068^{\star *} & .036^{\star \star} & .010^{\star *} & -.024^{\star \star} & -.019^{\star *} & -.026^{\star *}
\end{array} \\
& \begin{array}{lllllll}
-.074^{\star *} & .085^{\star \star} & .009^{\star *} & -.022^{\star *} & -.028^{\star *} & -.015^{\star *} & .653^{\star *}
\end{array}
\end{aligned}
$$$$
\text { 4. Skills development }
$$$$
\text { 5. Career perspectives }
$$$$
\text { 6. Teachers' gender }
$$$$
\text { 7. Teaching experience in the school }
$$

8. Overall teaching experience

$\begin{array}{llllllll}.076^{\star *} & -.013^{\star *} & -.001 & -.071^{\star *} & .017^{\star *} & -.050^{\star *} & .055^{\star *} & .087^{\star *}\end{array}$

9. Certification

Note: ${ }^{\star \star} p<.01$.

\subsection{Multiple Linear Regression}

Table 5 presents the results of the multiple regressions: linguistic diversity in the classroom $(\mathrm{t}=-.029 ; p<.001)$, teachers gender $(\mathrm{t}=-10.49 ; p<.001)$, teaching experience in the school $(\mathrm{t}=-5.46 ; p<.001)$, overall teaching experience $(\mathrm{t}=$ $-10.03 ; p<.001)$, and certification $(\mathrm{t}=-15.96 ; p<.001)$ negatively but weakly predicted skills development, while feedback on my collaboration/support practices with the students $(\mathrm{t}=111.78 ; p<.001)$ and feedback on my teaching/assessment practices $(\mathrm{t}=102.36 ; p<.001)$ offered a weak yet positive prediction. Together, however, these variables explain $17.8 \%$ of skills development.

As for the development of career perspectives, aside from teaching experience in the school, which was not significant, the following variables produced a weak positive prediction: linguistic diversity in the classroom $(\mathrm{t}=9.03 ; p<.001)$; feed-

\begin{tabular}{|c|c|c|c|c|c|c|}
\hline \multirow{2}{*}{ Variables } & \multicolumn{3}{|c|}{ Skills Development } & \multicolumn{3}{|c|}{ Career Perspectives } \\
\hline & $\mathrm{B}$ & SE & $\beta$ & $\mathrm{B}$ & SE & $\beta$ \\
\hline Linguistic diversity in the classroom & -.024 & .002 & $-.029^{\star * \star}$ & .022 & .002 & $.026^{\star * *}$ \\
\hline Feedback on my collaboration and support practices & .307 & .003 & $.307^{\star * *}$ & .284 & .003 & $.284^{\star * \star}$ \\
\hline Feedback on my teaching and assessment practices & .279 & .003 & $.282^{\star * *}$ & .185 & .003 & $.186^{\star * *}$ \\
\hline Teachers' gender & -.026 & .006 & $-.012^{\star * *}$ & .133 & .006 & $.063^{\star * *}$ \\
\hline Teaching experience in the school & -.012 & .002 & $-.020^{* * *}$ & .000 & .002 & .000 \\
\hline Overall teaching experience & -.018 & .002 & $-.037^{\star * *}$ & -.026 & .002 & $-.054^{* * *}$ \\
\hline Certification & -.150 & .009 & $-.044^{\star * *}$ & .107 & .010 & $.031^{\star * \star}$ \\
\hline $\mathbf{R}^{2}$ & \multicolumn{3}{|c|}{.178} & \multicolumn{3}{|c|}{.115} \\
\hline $\mathbf{F}$ & \multicolumn{3}{|c|}{$3394.79^{* * *}$} & \multicolumn{3}{|c|}{$2050.928^{* * *}$} \\
\hline
\end{tabular}
back on my collaboration/assessment practices with the students $(\mathrm{t}=99.66 ; p$ $<.001)$; feedback on my teaching/ assessment practices $(\mathrm{t}=65.28 ; p<.001)$; gender $(\mathrm{t}=22.01 ; p<.001)$; and certification $(\mathrm{t}=10.99 ; p<.001)$. Together, they explain $11.5 \%$ of the teachers' career perspectives.

Table 5. Predicting teacher professional development: regression results.

Note $^{1}:{ }^{* *} p<.001$. Note ${ }^{2}: \mathrm{B}=$ unstandardized coefficients for regression; $\mathrm{SE}=$ standard error; $\beta=$ standardized coefficients for regression; $\mathrm{R}^{2}$ = adjusted $\mathrm{r}$-square; $\mathrm{F}=$ mean square regression. 


\section{Discussion and Conclusion}

We sought to identify the relationships between teacher professional development and their perceptions of the feedback they received in light of their socioprofessional characteristics in a context of linguistic diversity in the classroom.

We recall that our factor analyses on the items of Question 30 regarding teacher professional development enabled us to identify two predominant teacher-related factors, namely, 1) skills development and 2) career perspectives. The factor analysis on the 11 items of Question 29 on the importance given to the supervisors feedback made it possible to identify two main factors: 1) feedback regarding the teacher's collaboration and support practices with their students and 2) that regarding their teaching and assessment practices.

Correlation analyses were then performed between five factors: feedback on my collaboration/support practices with the students, feedback on my teaching/ assessment practices, skills development, career perspectives, linguistic diversity in the classroom; and four teacher-related socioprofessional characteristics (Table 4).

\subsection{Presence of Linguistic Diversity in the Classroom}

In the presence of this diversity, despite having a greater level of teacher certification, the teachers valued to a lesser extent the importance of the feedback they received regarding their collaboration/support practices and teaching/assessment practices. The feedback included comments from the principals, colleagues, external individuals or bodies, students, students' parents or guardians and regarded the following: actions to help colleagues improve their teaching practices and how I collaborate with peers, how I teach in multiculturall multilingual settings and with special needs students, my competency in as well as my knowledge and mastery of my main subject field(s); my teaching and assessment practices, my student behavior/classroom management practices, and my students performance. Consequently, their skills were shown to decrease while their career perspectives increased.

\subsection{Absence of Linguistic Diversity in the Classroom}

In the absence of linguistic diversity in the classroom, the teachers in our study gave greater importance to the same factors as those mentioned above but were shown to be less certified. Consequently, their skills increased while their career perspectives decreased.

According to the results of our hierarchical regression analyses (see Appendix 1), the development of the teacher's skills and their professional growth perspectives were influenced differently, depending on the presence or absence of linguistic diversity in the classroom. When diversity was present, it explained the decrease in their skill level and the increase in their career perspectives, and when diversity was absent, this had a positive impact on skills development and a negative effect on career development. These observed differences were ampli- 
fied by the teachers' gender, teaching experience, whether they possessed a teaching degree or not, and particularly the level of importance they gave given to their supervisors' feedback regarding their teaching and assessment practices and collaboration and support practices with their students.

When linguistic diversity was present in the classroom, decreased skills development was attributed to male teachers, to their lack of experience in the school, their overall lack of teaching experience, and the low importance they gave to their supervisor's feedback, despite possessing a teaching degree. On the other hand, when linguistic diversity was absent, the increased skills were attributed to female teachers, their amount of teaching experience in the school, their overall teaching experience, and the significant value they awarded to the feedback they received, despite not having a teaching certificate.

However, our results also demonstrate that the presence of linguistic diversity in the classroom predicted an increase in the teachers' career perspectives, while absent diversity predicted the opposite. These observations support our previous findings (Azovide \& Bouchamma, 2021) showing that student linguistic diversity helps teachers to develop their perspectives for professional growth. This prediction is corroborated in the present work by the teachers' male gender, their lack of overall teaching experience, secured certification, and the consideration for the supervisor's feedback.

In other words, having a teaching degree does not in itself constitute a key factor determining skills development, contrary to the degree of importance given to the feedback they receive, which is determinant. These conclusions are in agreement with those of several other studies as to the positive impact of supervisors' feedback on the development of teaching competency (Atwater \& Brett, 2005; Banks \& Banks, 2019; Bouchamma, 2005; Bouchamma \& Tardif, 2011; Kalule \& Bouchamma, 2013; Memduhoglu, 2012; Mitchell \& Sackney, 2011; OECD, 2016). We now also have evidence that the presence of linguistic diversity in the classroom and having a teaching degree contribute favorably to teachers' career perspectives.

That said, the advent of classrooms having more than one linguistic group has created several challenges for teacher training (OECD, 2018), which must be addressed. Indeed, in situations involving student linguistic diversity, teachers tend to ignore the feedback they receive on how they teach, which may be explained by the gap evidenced between the specific competencies required in contexts of diversity and the supervisors' existing skills (Azovide \& Bouchamma, 2021; Bouchamma, 2016; Bouchamma \& Tardif, 2011; Lambert \& Bouchamma, 2019; Larochelle-Audet et al., 2018). It is thus imperative that the initial training and continuing education of both teachers and their supervisors be adjusted to consider the students' contextual characteristics (Moldoveanu \& Mujawamariya, 2007).

\section{Implications and Limitations}

This quantitative study exposed the point of view of both the supervisors and their supervised teachers and determined their relationship and influence in the 
presence or absence of linguistic diversity in the classroom. Here, the supervisors' feedback covered many aspects, such as the teachers' pedagogical and assessment practices, student support actions, and collaboration habits with colleagues and the students' parents, while the teachers' perspective was examined, in light of the importance they gave to the feedback they received.

Our results show that how well the teachers valued their supervisors' feedback was a determining factor favoring the development of their pedagogical competencies and professional growth perspectives. The supervisor's feedback effectively helped to develop the teachers' skills when the latter highly valued this feedback and possessed the necessary experience and hindsight to do so. However, in the presence of diversity in their classroom, often inexperienced teachers were shown to be ill-prepared to highly value their supervisors' feedback, which explains the progressive decrease in their skill level. Our findings also indicate that the pedagogical role of the teacher evolves and is supported by their supervisors' feedback and that merely having a diploma is not enough to prepare them to develop their competencies with multilingual groups of students.

We demonstrate that teachers gain from not only providing feedback to their peers but also welcoming the feedback they receive from these colleagues, as these actions support professional growth. Furthermore, to effectively contribute to making teaching practices better, the supervisor's feedback must hone in on the teachers' actual needs and socioprofessional contexts as well as those involving the students.

Although our use of TALIS 2013 survey data may be viewed as a limitation, due to their date of publication, these data remain relevant as they have been the subject of no other study of this nature. We are pursuing our analyses of the 2018 data, which were made available in 2020.

\section{Conflicts of Interest}

The authors declare no conflicts of interest regarding the publication of this paper.

\section{References}

Appave, G., \& David, I. (2017). Integration That Values Diversity-Exploring a Model for Current Migration Dynamics. In M. McAuliffe, \& M. Klein Solomon (Eds.), Migration Research Leaders' Syndicate: Ideas to Inform International Cooperation on Safe, Orderly and Regular Migration (pp. 159-167). OIM.

Atwater, L. E., \& Brett, J. F. (2005). Antecedents and Consequences of Reactions to Developmental 360 Feedbacks. Journal of Vocational Behavior, 66, 532-548. https://doi.org/10.1016/j.jvb.2004.05.003

Azovide, Y., \& Bouchamma, Y. (2021). Teacher Supervision in the Context of Linguistic Diversity in OECD Countries. Creative Education, 12, 1103-1117. https://doi.org/10.4236/ce.2021.125082

Banks, J. A., \& Banks, C. A. M. (Eds.) (2019). Multicultural Education: Issues and Perspectives. John Wiley \& Sons.

Bouchamma, Y. (2005). Evaluating Teaching Personnel. Which Model of Supervision Do 
Canadian Teachers Prefer? Journal of Personnel Evaluation in Education, 18, 289-308. https://doi.org/10.1007/s11092-007-9025-8

Bouchamma, Y. (2008). Les défis de l'école en milieu minoritaire francophone face à l'intégration des élèves immigrants [Francophone Minority Schools and the Challenges of Integrating Immigrant Students]. Revue Thèmes Canadiens, 120-123.

Bouchamma, Y. (2009). L'intervention interculturelle en milieu scolaire [Intercultural Intervention in Schools]. Caraquet, NB: Les éditions de la Francophonie.

Bouchamma, Y. (2011). Écoles efficaces: Quelles compétences des directions d'école en matière d'accompagnement du personnel enseignant? [Effective Schools: Best Teacher Supervision Practices]. In M. Moldoveanu (Ed.), Les compétences des acteurs de l'éducation [Educators' Competencies] (pp. 19-36). Éditions Peisaj.

Bouchamma, Y. (2015). L'école et l'immigration-Défis et pratiques gagnantes [School and Immigration: Challenges and Winning Practices]. Éditions de la Francophonie.

Bouchamma, Y. (2016). Les compétences des directions d'école en matière de diversité ethnoculturelle. La diversité ethnoculturelle, religieuse et linguistique en éducation au Québec [Principal Competency in Contexts of Ethnocultural Diversity. Ethnocultural, Religious, and Linguistic Diversity in Education in Québec]. Théorie et Pratique, 128-132.

Bouchamma, Y., \& April, D. (2021). School Principals' Competency Standards for the Effective Management of Ethnocultural Diversity. International Studies in Educational Administration (Commonwealth Council for Educational Administration \& Management (CCEAM)), 49, 69-119.

Bouchamma, Y., \& Tardif, C. (2011). Les pratiques des directions d'écoles en contexte de diversité ethnoculturelle [Principals' Practices in a Context of Ethnocultural Diversity]. In F. Kanouté, \& G. Lafortune (Eds.), Familles québécoises d'origine immigrante: Les dynamiques de l'établissement [Québec Families of Immigrant Origin: The School Dynamics] (pp. 87-96). Presses de l'Université de Montréal. https://doi.org/10.4000/books.pum.8912

Branch, G. F., Hanushek, E. A., \& Rivkin, S. G. (2012). Estimating the Effect of Leaders on Public Sector Productivity: The Case of School Principals (No. w17803). National Bureau of Economic Research. https://doi.org/10.3386/w17803

Broadfoot, P. (2000). Un nouveau mode de régulation dans un système décentralisé: L'État évaluateur [New Regulation of a Decentralized System: The State Evaluates]. Revue Française de Pédagogie, 130, 43-55. https://doi.org/10.3406/rfp.2000.1052

Brown, K. E., \& Medway, F. J. (2007). School Climate and Teacher Beliefs in a School Effectively Serving Poor South Carolina (USA) African-American Students: A Case Study. Teaching and Teacher Education, 23, 529-540. https://doi.org/10.1016/j.tate.2006.11.002

Cameron, G., Goldin, I., \& Balarajan, M. (2011). Exceptional People: How Migration Shaped Our World and Will Define Our Future. Princeton University Press. https://doi.org/10.1515/9781400836291

Castles, S. (2010). Understanding Global Migration: A Social Transformation Perspective. Journal of Ethnic and Migration Studies, 26, 1565-1586. https://doi.org/10.1080/1369183X.2010.489381

Castles, S., Korac, M., Vasta, E., \& Vertovec, S. (2002). Integration: Mapping the Field. Report by the University of Oxford Centre for Migration and Policy Research and Refugee Studies Centre.

Coburn, C. E. (2004). Beyond Decoupling: Rethinking the Relationship between the Institutional Environment and the Classroom. Sociology of Education, 77, 211-244.

https://doi.org/10.1177/003804070407700302 
Collerette, P., Pelletier, D., \& Turcotte, G. (2013). Recueil de pratiques des directions d'écoles secondaires favorisant la réussite des élèves [High School Principals' Winning Practices to Improve Student Learning]. Université du Québec en Outaouais.

Cooper, C. W. (2009). Performing Cultural Work in Demographically Changing Schools: Implications for Expanding Transformative Leadership Frameworks. Educational Administration Quarterly, 45, 694-724. https://doi.org/10.1177/0013161X09341639

Crum, K. S., \& Sherman, W. H. (2008). Facilitating High Achievement: High School Principals' Reflections on Their Successful Leadership Practices. Journal of Educational Administration, 46, 562-580. https://doi.org/10.1108/09578230810895492

Czaika, M., \& de Haas, H. (2014). The Globalization of Migration: Has the World Become More Migratory? International Migration Review, 18, 283-323.

https://doi.org/10.1111/imre.12095

Datnow, A., \& Castellano, M. E. (2001). Managing and Guiding School Reform: Leadership in Success for All Schools. Educational Administrative Quarterly, 37, 219-249. https://doi.org/10.1177/00131610121969307

De Witte, M. (2018). Stanford Research Explores the Complexities of Global Immigration, from Past to Present. Stanford News. https://news.stanford.edu/2018/04/18/examining-complexities-migration/

Demireva, N. (2017). Immigration, Diversity and Social Cohesion. A Migration Observatory Brief, University of Oxford.

Deniger, M.-A., Larivée, S. J., Rodrigue, S., \& Morin, M. (2013). Enquête sur les relations école-famille-communauté à la Commission scolaire de Montréal [Enquiry on SchoolFamily-Community Relations in the Montréal School Commission]. Université de Montréal.

Dinham, S. (2005). Principal Leadership for Outstanding Educational Outcomes. Journal of Educational Administration, 43, 338-356. https://doi.org/10.1108/09578230510605405

Dionne, L., Savoie-Zajc, L., \& Couture, C. (2013). Les rôles de l'accompagnant au sein d'une communauté d'apprentissage d'enseignants. Revue Canadienne de l'Éducation, 36, 175-201.

DuFour, R., DuFour, R. B., Eaker, R. E., \& Karhanek, G. (2004). Whatever It Takes: How Professional Learning Communities Respond When Kids Don't Learn. National Educational Service.

https://staffweb.psdschools.org/cshaw/May\%2030,\%202013/Other/How\%20PLCs\%20R espond\%20When\%20Kids\%20Don't\%20Learn.pdf

Dumay, X., Cattonar, B., Maroy, C., \& Mangez, C. (2013). Modalités de mise en oeuvre des instruments d'évaluation et institutionnalisation de la régulation par les résultats dans les établissements scolaires [Implementation of Assessment and Management Tools Using School Data]. In C. Maroy (Ed.), L'école à l'épreuve de la performance. Les politiques de régulation par les résultats [School and Performance: Results-Based Management] (pp. 125-139). De Boeck.

Duval, J., Dumoulin, C., \& Perron, M. (2014). Collaboration école-famille et prévention du décrochage scolaire: Des pistes d'action pour les enseignants du primaire [SchoolFamily Collaboration and Dropout Prevention: Measures for Primary School Teachers]. Revue Canadienne de l'Éducation, 37, 1-23.

Hall, K., \& Posel, D. (2019). Fragmenting the Family? The Complexity of Household Migration Strategies in Post-Apartheid South Africa. IZA Journal of Development and Migration, 10, 1-20. https://doi.org/10.2478/izajodm-2019-0004

Hoy, A. W., \& Hoy, W. K. (2003). Instructional Leadership: A Learning-Centered Guide. 
Allyn and Bacon.

Kalule, L., \& Bouchamma, Y. (2013). Teacher Supervision Practices: What Do Teachers Think? International Studies in Educational Administration, 40, 91-104.

Kluger, A. N., \& DeNisi, A. (1996). The Effects of Feedback Interventions on Performance: A Historical Review, a Meta-Analysis, and a Preliminary Feedback Intervention Theory. Psychological Bulletin, 119, 254-284. https://doi.org/10.1037/0033-2909.119.2.254

Koser, K. (2016). International Migration: A Very Short Introduction. Oxford University Press. https://doi.org/10.1093/actrade/9780198753773.001.0001

Lambert, M., \& Bouchamma, Y. (2019). The Development of Competencies Required for School Principals in Quebec: Adequacy between Competency Standard and Practice. Education Policy Analysis Archives, 27, 116. https://doi.org/10.14507/epaa.27.4211

Larochelle-Audet, J., Magnan, M. O., Potvin, M., \& Doré, E. (2018). Les compétences des directions en matière d'équité et de diversité: Pistes pour les cadres de référence et la formation [Fairness and Diversity in Schools: Suggested Skills for Principals' Competency Standards and Training].

https://papyrus.bib.umontreal.ca/xmlui/bitstream/handle/1866/22715/Groupe-directio ns rapport avril2018 vf.pdf? sequence $=1$

Laveault, D., Dionne, E., Lafontaine, D., Tessaro, W., \& Allal, L. (2014). L'évaluation des compétences en salle de classe: Régulations entre politiques et pratiques [Competency Assessment in the Classroom: Between Policy and Practice]. In C. Dierendonck, E. Loarer, \& B. Rey (Eds.), L'évaluation des compétences en milieu scolaire et en milieu professionnel [Evaluating Competency in School and in the Professional Environment] (pp. 85-96). De Boeck.

Leithwood, K., Louis, K. S., Anderson, S., \& Wahlstrom, K. (2004). How Leadership Influences Student Learning. The Wallace Foundation. Center for Applied Research and Educational Improvement, Ontario Institute for Studies in Education.

Lindsey, D. B., Jungwirth, L. D., Pahl, J. V., \& Lindsey, R. B. (Eds.) (2009). Culturally Proficient Learning Communities: Confronting Inequities through Collaborative Curiosity. Corwin Press.

Marks, H. M., \& Nance, J. P. (2007). Contexts of Accountability under Systemic Reform: Implications for Principal Influence on Instruction and Supervision. Educational Administration Quarterly, 43, 3-37.

Maroy, C. (2005). Vers une régulation post-bureaucratique des systèmes d'enseignement en Europe? [Toward a Post-Bureaucratic Regulation of European Teaching Systems?] Cahiers de Recherche en Education et Formation, 40, 31-55. https://doi.org/10.7202/019471ar

Marshall, K. (2005). It's Time to Rethink Teacher Supervision and Evaluation. Phi Delta Kappan, 86, 727-735. https://doi.org/10.1177/003172170508601004

Marzano, R. J., Frontier, T., \& Livingston, D. (2011). Effective Supervision: Supporting the Art and Science of Teaching. Association for Supervision and Curriculum Development.

McAuliffe, M., \& Khadria, B. (2020). World Migration Report 2020. International Organization for Migration. https://publications.iom.int/system/files/pdf/wmr 2020.pdf

Memduhoglu, H. B. (2012). The Issue of Education Supervision in Turkey in the Views of Teachers, Administrators, Supervisors, and Lecturers. Educational Sciences: Theory and Practice, 12, 149-156.

Mitchell, C., \& Sackney, L. (2011). Profound Improvement: Building Capacity for a Learning Community. Taylor \& Francis. https://doi.org/10.4324/9780203826027 
Moldoveanu, M., \& Mujawamariya, D. (2007). Multicultural Education in the Initial Training of Teachers: From Policies to Practices. McGill Journal of Education, 42, 31-46.

Newland, K. (2017). Migrant Return and Reintegration Policy: A Key Component of Migration Governance. In M. McAuliffe, \& M. Klein Solomon (Eds.), Migration Research leaders' Syndicate: Ideas to Inform International Cooperation on Safe, Orderly and Regular Migration (pp. 169-173). OIM.

Nolan, J. F., \& Hoover, L. A. (2008). Teacher Supervision and Evaluation: Theory into Practice (2nd ed.). Wiley.

OECD (2016). Teacher Professionalism: Teaching in Focus. 2016/14. https://doi.org/10.1787/5jm3xgskpc40-en

OECD (2018). La résilience des élèves issus de l'immigration: Les facteurs qui déterminent le bien-être [Resilient Immigrant-Origin Students: What Determines Well-Being].

Oliva, P. F., \& Pawlas, G. E. (2001). Supervision for Today's Schools (6th ed.). John Wiley and Sons.

Ovando, M. N. (2005). Building Instructional Leaders' Capacity to Deliver Constructive Feedback to Teachers. Journal of Personnel Evaluation in Education, 18, 171-183.

https://doi.org/10.1007/s11092-006-9018-Z

Ovando, M. N., \& Harris, B. M. (1993). Teachers' Perceptions of the Post-Observation Conference: Implications for Formative Evaluation. Journal of Personnel Evaluation in Education, 7, 301-310. https://doi.org/10.1007/BF00972507

Panagiotopoulou, J. A., \& Rosen, L. (2018). Denied Inclusion of Migration-Related Multilingualism: An Ethnographic Approach to a Preparatory Class for Newly Arrived Children in Germany. Language and Education, 23, 394-409. https://doi.org/10.1080/09500782.2018.1489829

Robinson, V. M. J. (2007). School Leadership and Student Outcomes: Identifying What Works and Why. Australian Council for Educational Leaders.

Silva, D. Y., \& Dana, N. F. (2001). Collaborative Supervision in the Professional Development School. Journal of Curriculum and Supervision, 16, 305-321.

Silver, H. (2015). The Contexts of Social Inclusion (Work Document No. 144, ST/ESA/ 2015/EWP/144). United Nations Department of Economic and Social Affairs.

Somers, T. (2018). Multilingualism for Europeans, Monolingualism for Immigrants? Towards Policy-Based Inclusion of Immigrant Minority Language Students in Content and Language Integrated Learning (CLIL). European Journal of Language Policy, 10, 203-228. https://doi.org/10.3828/ejlp.2018.12

Tobin, M. B. (2008). The $360^{\circ}$ Evaluation in an Educational Setting. Exchange, No. 184, 56-59.

Triandafyllidou, A. (2018). Globalisation and Migration. In A. Triandafyllidou (Ed.), Handbook on Migration and Globalisation (pp. 1-13). Edward Elgar. https://doi.org/10.4337/9781785367519

Zepeda, S. J. (2012). Instructional Supervision: Applying Tools and Concepts (3rd ed.). Eye on Education.

Zetter, R., Griffiths, D., Sigona, N., Flynn, D., Pasha, T., \& Beynon, R. (2006). Immigration, Social Cohesion and Social Capital: What Are the Links? Oxford Brookes University, Joseph Rowntree Foundation. 


\section{Appendix 1}

\section{Hierarchical Regression Results}

Table A1. Hierarchical regressions of the variables predicting skills development.

\begin{tabular}{|c|c|c|c|c|c|c|c|c|c|}
\hline \multirow{2}{*}{ Variables } & \multicolumn{3}{|c|}{ Model 1} & \multicolumn{3}{|c|}{ Model 2} & \multicolumn{3}{|c|}{ Model 3} \\
\hline & $\mathrm{B}$ & SE & $\beta$ & $\mathrm{B}$ & SE & $\beta$ & $\mathrm{B}$ & SE & $\beta$ \\
\hline Linguistic diversity in the classroom & -.035 & .003 & $-.042^{* * *}$ & -.023 & .002 & $-.027^{\star * *}$ & -.024 & .013 & $.091^{\star * *}$ \\
\hline $\begin{array}{l}\text { Feedback on my collaboration and } \\
\text { support practices with the students }\end{array}$ & & & & .304 & .003 & $.304^{\star * *}$ & .307 & .037 & $.070^{* * *}$ \\
\hline $\begin{array}{l}\text { Feedback on my teaching and } \\
\text { assessment practices }\end{array}$ & & & & .280 & .003 & $.283^{\star * *}$ & .279 & .009 & $.066^{\star * *}$ \\
\hline Teachers' gender & & & & & & & -.026 & .006 & -.012 \\
\hline Teaching experience in the school & & & & & & & -.012 & .002 & -.020 \\
\hline Overall teaching experience & & & & & & & -.018 & .002 & -.037 \\
\hline Certification & & & & & & & -.15 & .009 & -.044 \\
\hline $\mathrm{R}^{2}$ & & .002 & & & .173 & & & .178 & \\
\hline $\mathrm{F}$ & & $193.954^{`}$ & & & $7645^{\star * *}$ & & & $3394.79^{* * *}$ & \\
\hline
\end{tabular}

Note $^{1}:{ }^{* \star} p<.001$. Note ${ }^{2}: \mathrm{B}=$ unstandardized coefficients for regression; $\mathrm{SE}=$ standard error; $\beta=$ standardized coefficients for regression; $\mathrm{R}^{2}$ = adjusted $\mathrm{r}$-square; $\mathrm{F}=$ mean square regression.

Table A2. Hierarchical regressions of the variables predicting career perspectives.

\begin{tabular}{|c|c|c|c|c|c|c|c|c|c|}
\hline \multirow{2}{*}{ Variables } & \multicolumn{3}{|c|}{ Model 1} & \multicolumn{3}{|c|}{ Model 2} & \multicolumn{3}{|c|}{ Model 3} \\
\hline & $\mathrm{B}$ & SE & $\beta$ & $\mathrm{B}$ & SE & $\beta$ & $\mathrm{B}$ & SE & $\beta$ \\
\hline Linguistic diversity in the classroom & .019 & .003 & $.022^{\star * *}$ & .028 & .002 & $.277^{\star * *}$ & .022 & .002 & $.026^{\star * *}$ \\
\hline $\begin{array}{l}\text { Feedback on my collaboration and } \\
\text { support practices with the students }\end{array}$ & & & & .199 & .037 & $.070^{\star * *}$ & .284 & .003 & $.284^{\star * *}$ \\
\hline $\begin{array}{l}\text { Feedback on my teaching and } \\
\text { assessment practices }\end{array}$ & & & & .178 & .003 & $.179^{* * *}$ & .185 & .003 & $.0186^{* * *}$ \\
\hline Teachers' gender & & & & & & & .133 & .006 & $.063^{\star * *}$ \\
\hline Teaching experience in the school & & & & & & & .000 & .002 & .000 \\
\hline Overall teaching experience & & & & & & & -.026 & .002 & $-.054^{* * *}$ \\
\hline Certification & & & & & & & .107 & .010 & $.031^{\star * *}$ \\
\hline $\mathrm{R}^{2}$ & & .0001 & & & .108 & & & .115 & \\
\hline $\mathrm{F}$ & & $54.696^{* * *}$ & & & $4442.06^{* * *}$ & & & $2050.92^{\star * *}$ & \\
\hline
\end{tabular}

Note $^{1}:{ }^{* *} p<.001$. Note $^{1}:{ }^{\star * \star} p<.001$. Note ${ }^{2}: \mathrm{B}=$ unstandardized coefficients for regression; $\mathrm{SE}=$ standard error; $\beta=$ standardized coefficients for regression; $\mathrm{R}^{2}=$ adjusted $\mathrm{r}$-square; $\mathrm{F}=$ mean square regression. 


\section{Appendix 2}

\section{OECD's Teaching and Learning International Survey (TALIS, 2013)}

\section{TEACHER QUESTIONNAIRE}

1. Are you female or male? $\quad$ 1. Female 2. Male

5. How many years of work experience do you have?

a) Year(s) working as a teacher at this school

b) Year(s) working as a teacher in total

11. Did you complete a teacher education or training programme?

1. Yes

2. No

19. In your first regular employment as a teacher, did/do you take part in any induction programme?
1. Yes
2. No

a) I took/take part in an induction programme

29. In your opinion, when you receive this feedback, what is the emphasis placed on the following areas?

TT2G29A Student performance

TT2G29B Knowledge and understanding of my main subject field(s)

TT2G29C Pedagogical competencies in teaching my main subject field(s)

TT2G29D Student assessment practices

TT2G29E Student behaviour and classroom management

1. Not considered at all

TT2G29F Teaching of students with special needs

2. Considered with low importance

TT2G29G Teaching in a multicultural or multilingual setting

3. Considered with moderate importance

TT2G29H The feedback I provide to other teachers to improve their teaching

4. Considered with high importance

TT2G29I Feedback from parents or guardians

TT2G29J Student feedback

TT2G29K Collaboration or working with other teachers

30. Concerning the feedback you have received at this school, to what extent has it directly led to a positive change in any of the following?

TT2G30A Your public recognition from the principal and/or your colleagues

TT2G30B Your role in school development initiatives (e.g. curriculum development group, development of school objectives)

TT2G30C The likelihood of your career advancement (e.g. promotion)

TT2G30D The amount of professional development you undertake

TT2G30E Your job responsibilities at this school

TT2G30F Your confidence as a teacher

TT2G30G Your salary and/or financial bonus

TT2G30H Your classroom management practices

1. No positive change

2. A small change

3. A moderate change

4. A large change

TT2G30I Your knowledge and understanding of your main subject field(s)

TT2G30J Your teaching practices

TT2G30K Your methods for teaching students with special needs

TT2G30L Your use of student assessments to improve student learning 


\section{Continued}

TT2G30M Your job satisfaction

TT2G30N Your motivation

35. We would like to understand the composition of the "target class". Please estimate the broad percentage of students who have the following characteristics:

\section{None}

2. $1 \%$ and $10 \%$

TT2G35A Students whose [first language] is different from the language(s) of instruction or from a dialect of this/these language(s)

3. $11 \%$ to $30 \%$

4. $31 \%$ to $60 \%$

5. More than $60 \%$ 